\title{
The virulence of Enterobacter cloacae and Serratia marcescens in experimental bladder infection in diabetic mice
}

\author{
Y. OBANA and T. NISHINO \\ Department of Microbiology, Kyoto Pharmaceutical University, 5 Nakauchi-cho, Misasagi, Yamashina, Kyoto \\ 607, Japan
}

Summary. Diabetic mice were significantly more susceptible than normal mice to bladder infection with Enterobacter cloacae or Serratia marcescens but not to intraperitoneal infection. Normal urine inhibited the growth of $E$. cloacae and $S$. marcescens, whereas urine from diabetic mice permitted multiplication. The addition of urea to urine from diabetic mice restored its antibacterial properties for E. cloacae and $S$. marcescens. We consider that the decreased urea content of the urine of diabetic mice was responsible for their increased susceptibility to bacterial infection of the bladder.

\section{Introduction}

Patients with diabetes mellitus have an increased susceptibility to infectious diseases. In such patients, the three most common sites of infection are the lung, skin and urinary tract (Forland et al., 1977). Furthermore, studies in rabbits, rats and mice with chemically induced diabetes have sometimes, though not always (Cruickshank, 1954), shown increased susceptibility to various bacterial and fungal infections (Raffel et al., 1981; Edwards and Fuselier, 1983; Obana et al., 1987).

The present investigation was undertaken to determine the effects of alloxan-induced diabetes on experimental bladder infections in mice due to Enterobacter cloacae and Serratia marcescens, bacterial species frequently isolated from immunocompromised patients, and to compare the antimicrobial properties of urine obtained from normal and diabetic mice.

\section{Materials and methods}

\section{Bacteria}

Seven strains each of $E$. cloacae and $S$. marcescens were used. E. cloacae strain 113 and $S$. marcescens strain K-3 were isolated from the urine of patients with urinary tract infections. The source of the other strains was unknown. Cultures were maintained on Nutrient Agar slopes (Nissui Pharmaceutical Co., Ltd) at room temperature.

Received 27 Sep. 1988; revised version accepted 1 Feb. 1989.

\section{Animals}

Std-ddY female mice weighing 20-22 g were obtained from the Shizuoka Agricultural Cooperative Association for Laboratory Animals.

\section{Induction of diabetes}

The method of producing diabetes has been described in detail elsewhere (Obana et al., 1985b). Four days after the intraperitoneal injection of alloxan monohydrate (Nakarai Chemicals, Ltd) at a dose of $250 \mathrm{mg} / \mathrm{kg}$ body weight, urine from each animal was examined for glucose by means of N-Multistic ${ }^{\circledR} \mathrm{SG}$ (Miles-Sankyo Co., Ltd). Animals with glycosuria (glucose $>10.0 \mathrm{mg} / \mathrm{ml}$ ) were used for the study.

\section{Intraperitoneal infection}

The test bacteria were cultured in Nutrient Broth (Nissui Pharmaceutical Co., Ltd) at $37^{\circ} \mathrm{C}$ for $18 \mathrm{~h}$. Serial 10 -fold dilutions of this culture were mixed with an equal volume of $6 \%$ hog gastric mucin (Nakarai Chemicals, Ltd); each dilution was used to inoculate 10 mice intraperitoneally (dose $0.5 \mathrm{ml}$ ). Control mice received similar inocula in which mucin was replaced by sterile diluent. The final mortality was recorded 3 days after inoculation.

\section{Bladder infection}

Normal and diabetic mice whose water supply had been restricted for a period of $3 \mathrm{~h}$ were given bladder infections with $E$. cloacae strain 113 or $S$. marcescens strain $\mathrm{K}-3$ by urethral inoculation, in a dose volume of 
$0.05 \mathrm{ml}$ (see Obana et al., 1985a). The mice were killed $24 \mathrm{~h}$ after inoculation and their bladders were removed aseptically. Each bladder with its contents was homogenised in sterile physiological saline, and dilutions were plated to obtain colony counts.

\section{Collection of urine and determination of its antimicrobial activity}

Groups of 10 mice each were forced to void urine by gentle compression of the bladder through the external abdominal wall. In each group the urine samples were pooled and sterilised by filtration through a $0.45-\mu \mathrm{m}$ filter. Sterilised urine samples not used in experiments on the same day were stored at $-20^{\circ} \mathrm{C}$. The urea nitrogen content of pooled urine from groups of normal and diabetic mice was measured by the urease-indophenol method (Okuda et al., 1981). Growth of the bacterial strains in the urine samples was then studied. Nutrient broth was seeded from a stock culture and incubated at $37^{\circ} \mathrm{C}$ for $18 \mathrm{~h}$. For each test $c .10^{6}$ organisms, contained in $0.1 \mathrm{ml}$ of an appropriate saline dilution of broth culture, were inoculated into $0.9 \mathrm{ml}$ of urine preheated to $37^{\circ} \mathrm{C}$. Immediately, and again after incubation for 2 and $4 \mathrm{~h}$ at $37^{\circ} \mathrm{C}$, a sample was removed from the tube to determine the viable count.

\section{Effect of urea on the growth of bacteria}

The effect of different concentrations of urea on the growth of E. cloacae and $S$. marcescens was examined in nutrient broth adjusted to $\mathrm{pH} 6 \cdot 5$. Nutrient broth seeded with stock culture was incubated at $37^{\circ} \mathrm{C}$ for $18 \mathrm{~h}$ and then diluted in nutrient broth, $\mathrm{pH} 6.5$, to a concentration of $c .10^{5}$ organisms $/ \mathrm{ml}$. The diluted culture was transferred in $4.5-\mathrm{ml}$ volumes to test tubes, which were then placed in a water bath $\left(37^{\circ} \mathrm{C}\right)$ before the addition of 0.5 - $\mathrm{ml}$ volumes of medium containing 10 times the required final concentration of urea. Immediately, and again after incubation for 2 and $4 \mathrm{~h}$ at $37^{\circ} \mathrm{C}$, a sample was removed from each tube to determine the viable count.

\section{Results}

\section{Intraperitoneal infection}

Normal and diabetic mice did not differ significantly in their susceptibility to intraperitoneal infection with $E$. cloacae strain 113 or $S$. marcescens strain K-3 (table I).

\section{Bladder infection}

Table II shows that diabetic mice were strikingly more susceptible than normal mice to experimental infection of the bladder with $E$. cloacae strain 113 and $S$. marcescens strain K-3.

\section{Antibacterial activity of urine and urea}

Table III shows that seven strains each of $E$. cloacae and $S$. marcescens invariably gave higher viable counts after incubation in the urine of diabetic mice ( $\mathrm{pH} 6.2$; urea nitrogen $14.9 \mathrm{mg} / \mathrm{ml})$ than in normal urine (pH6.5; urea nitrogen $37 \mathrm{mg}$ / $\mathrm{ml}$ ). Table IV shows that the antibacterial properties of normal urine could be conferred on urine from diabetic mice by the addition of urea. Similar results were obtained by the addition of urea to nutrient broth (table V). Furthermore, the addition of glucose $20 \mathrm{mg} / \mathrm{ml}$ to normal urine to simulate

Table I. Virulence of Enterobacter cloacae 113 and Serratia marcescens K-3 for normal and diabetic mice by the intraperitoneal route

\begin{tabular}{|c|c|c|c|c|c|}
\hline \multirow[b]{3}{*}{ Organism } & \multirow[b]{3}{*}{$\begin{array}{l}\text { Dose of viable orga- } \\
\text { nisms }\left(\log _{10}\right) / \text { mouse }\end{array}$} & \multicolumn{4}{|c|}{ Mortality $(\%)$ produced by intraperitoneal infection } \\
\hline & & \multirow{2}{*}{\multicolumn{2}{|c|}{$\begin{array}{c}\text { with mucin, in groups of } \\
10 \\
\text { normal mice diabetic mice }\end{array}$}} & \multirow{2}{*}{\multicolumn{2}{|c|}{$\begin{array}{l}\text { without mucin, in groups of } \\
10\end{array}$}} \\
\hline & & & & & \\
\hline E. cloacae 113 & $\begin{array}{l}7 \cdot 54 \\
6 \cdot 54 \\
5 \cdot 54 \\
4 \cdot 54\end{array}$ & $\begin{array}{r}100 \\
100 \\
60 \\
0\end{array}$ & $\begin{array}{r}100 \\
80 \\
50 \\
0\end{array}$ & $\begin{array}{c}0 \\
0 \\
0 \\
\text { ND }\end{array}$ & $\begin{array}{c}10 \\
0 \\
0 \\
\text { ND }\end{array}$ \\
\hline S. marcescens $\mathrm{K}-3$ & $\begin{array}{l}7 \cdot 70 \\
6 \cdot 70 \\
5 \cdot 70 \\
4 \cdot 70\end{array}$ & $\begin{array}{r}70 \\
20 \\
0 \\
0\end{array}$ & $\begin{array}{r}80 \\
10 \\
0 \\
0\end{array}$ & $\begin{array}{c}0 \\
0 \\
\text { ND } \\
\text { ND }\end{array}$ & $\begin{array}{c}0 \\
0 \\
\text { ND } \\
\text { ND }\end{array}$ \\
\hline
\end{tabular}

$\mathrm{ND}=$ not done 
Table II. Bacterial counts in the bladders of normal and diabetic mice inoculated urethrally with E. cloacae 113 and $S$. marcescens K-3

\begin{tabular}{|c|c|c|c|c|}
\hline \multirow[b]{2}{*}{ Organism } & \multirow{2}{*}{$\begin{array}{l}\text { Dose of viable orga- } \\
\text { nisms }\left(\log _{10}\right) / \text { mouse }\end{array}$} & \multicolumn{2}{|c|}{$\begin{array}{l}\text { Counts }\left(\log _{10}\right)^{*} \text { of bacteria, } \\
24 \text { h after infection, in the } \\
\text { bladders of }\end{array}$} & \multirow[b]{2}{*}{$\mathrm{p}$ value $\dagger$} \\
\hline & & \multicolumn{2}{|c|}{ normal mice diabetic mice } & \\
\hline E. cloacae 113 & $5 \cdot 70$ & $4 \cdot 00(0 \cdot 32)$ & $7.27(0.47)$ & $<0.01$ \\
\hline & $4 \cdot 70$ & $3.00(0.42)$ & $6.67(0 \cdot 31)$ & $<0.01$ \\
\hline & $3 \cdot 70$ & $1.07(0.94)$ & $5 \cdot 67(1 \cdot 30)$ & $<0.01$ \\
\hline & $2 \cdot 70$ & $1.25(1.26)$ & $4 \cdot 47(2 \cdot 23)$ & $\leq 0.05$ \\
\hline S. marcescens K-3 & $5 \cdot 60$ & $3.27(0.89)$ & $6.73(0 \cdot 50)$ & $<0.01$ \\
\hline & $4 \cdot 60$ & $2.79(1.21)$ & $6.43(0.25)$ & $<0.01$ \\
\hline & $3 \cdot 60$ & $2 \cdot 08(1 \cdot 16)$ & $5 \cdot 24(1 \cdot 56)$ & $<0.05$ \\
\hline & $2 \cdot 60$ & 0 & $3.95(1.77)$ & \\
\hline
\end{tabular}

*Each value represents the mean (SD) of 5 mice.

†Student's $t$ test.

glycosuria did not appear to enhance multiplication of the bacterial strains tested (table IV).

\section{Discussion}

Clinicians have noted differences in the response of diabetic patients to opportunist infections, but there are few relevant laboratory studies. The present study showed that alloxan-induced diabetic mice were strikingly more susceptible than normal mice to bladder infection with $E$. cloacae or $S$. marcescens but not to intraperitoneal infection. This suggests that, for these two organisms, the virulence factors necessary for bladder infection differ from those for intraperitoneal infection.

The growth of bacteria in mouse urine is probably an essential preliminary to bladder infection. It has commonly been stated that urine is an excellent culture medium for the bacteria that cause urinary tract infection (Cox and Hinman, 1961), but Davis and Hain (1918) demonstrated that dog urine was bactericidal for gram-negative bacteria. Our studies

Table III. Growth of E. cloacae and S. marcescens in urine from normal and diabetic mice

\begin{tabular}{|c|c|c|c|c|c|c|}
\hline \multirow[b]{3}{*}{ Organism } & \multirow[b]{3}{*}{ Strain } & \multirow{3}{*}{$\begin{array}{l}\text { Bacterial counts } \\
\left(\log _{10} / \mathrm{ml}\right) \text { in urine } \\
\text { before incubation }\end{array}$} & \multicolumn{4}{|c|}{ Bacterial counts $\left(\log _{10} / \mathrm{ml}\right)$ in the urine of } \\
\hline & & & \multicolumn{2}{|c|}{$\begin{array}{c}\text { normal mice, after incuba- } \\
\text { tion for }\end{array}$} & \multicolumn{2}{|c|}{$\begin{array}{c}\text { diabetic mice, after incuba- } \\
\text { tion for }\end{array}$} \\
\hline & & & $2 \mathrm{~h}$ & $4 \mathrm{~h}$ & $2 \mathrm{~h}$ & $4 \mathrm{~h}$ \\
\hline \multirow[t]{7}{*}{ E. cloacae } & 106 & $5 \cdot 70$ & $6 \cdot 24$ & $6 \cdot 74$ & $7 \cdot 00$ & $8 \cdot 36$ \\
\hline & 108 & $5 \cdot 83$ & $6 \cdot 30$ & $6 \cdot 57$ & $7 \cdot 24$ & 8.40 \\
\hline & 110 & 5.72 & $6 \cdot 20$ & $6 \cdot 52$ & 6.89 & $8 \cdot 48$ \\
\hline & 112 & $5 \cdot 52$ & $5 \cdot 52$ & $5 \cdot 75$ & $6 \cdot 60$ & $7 \cdot 40$ \\
\hline & 113 & $5 \cdot 74$ & $6 \cdot 24$ & $6 \cdot 72$ & $7 \cdot 00$ & $8 \cdot 42$ \\
\hline & 114 & $5 \cdot 74$ & $6 \cdot 00$ & $6 \cdot 32$ & $7 \cdot 00$ & $8 \cdot 18$ \\
\hline & 718 & $5 \cdot 86$ & $6 \cdot 20$ & $6 \cdot 71$ & $7 \cdot 24$ & $8 \cdot 51$ \\
\hline \multirow[t]{7}{*}{ S. marcescens } & $\mathrm{K}-3$ & $5 \cdot 52$ & $5 \cdot 67$ & $5 \cdot 67$ & $6 \cdot 00$ & $7 \cdot 17$ \\
\hline & $\mathrm{K}-4$ & $5 \cdot 18$ & $5 \cdot 00$ & $4 \cdot 49$ & $6 \cdot 00$ & $6 \cdot 51$ \\
\hline & $\mathrm{K}-16$ & $5 \cdot 18$ & $5 \cdot 00$ & $4 \cdot 54$ & $5 \cdot 89$ & 6.44 \\
\hline & $\mathrm{T}-3$ & $5 \cdot 18$ & $5 \cdot 20$ & $5 \cdot 44$ & $6 \cdot 24$ & $7 \cdot 23$ \\
\hline & $\mathrm{T}-8$ & $5 \cdot 48$ & $5 \cdot 30$ & $5 \cdot 23$ & $6 \cdot 00$ & $6 \cdot 74$ \\
\hline & $\mathrm{T}-11$ & $5 \cdot 62$ & $5 \cdot 62$ & $5 \cdot 45$ & $6 \cdot 20$ & $7 \cdot 28$ \\
\hline & $\mathrm{T}-55$ & $5 \cdot 79$ & $5 \cdot 90$ & 5.90 & $6 \cdot 30$ & $7 \cdot 70$ \\
\hline
\end{tabular}


Table IV. Growth of E. cloacae 113 and $S$. marcescens K-3 in urine from normal mice, and in that from diabetic mice with and without the addition of urea

\begin{tabular}{|c|c|c|c|c|c|}
\hline \multirow[b]{3}{*}{ Urine } & \multirow[b]{3}{*}{ Urea added } & \multicolumn{4}{|c|}{$\begin{array}{l}\text { Bacterial counts }\left(\log _{10} / \mathrm{ml}\right) \text { after the stated periods of } \\
\text { incubation in urine seeded with }\end{array}$} \\
\hline & & \multicolumn{2}{|c|}{ E. cloacae $113^{*}$} & \multicolumn{2}{|c|}{ S. marcescens $\mathrm{K}-3 \dagger$} \\
\hline & & $2 \mathrm{~h}$ & $4 \mathrm{~h}$ & $2 \mathrm{~h}$ & $4 \mathrm{~h}$ \\
\hline \multirow[t]{3}{*}{ From diabetic mice } & None & $7 \cdot 10$ & $8 \cdot 41$ & $5 \cdot 84$ & 6.93 \\
\hline & $25 \mathrm{mg} / \mathrm{ml}$ & $6 \cdot 50$ & $7 \cdot 39$ & $5 \cdot 15$ & $5 \cdot 34$ \\
\hline & $50 \mathrm{mg} / \mathrm{ml}$ & $5 \cdot 70$ & $5 \cdot 63$ & $4 \cdot 89$ & $4 \cdot 32$ \\
\hline Normal & None & $6 \cdot 15$ & $6 \cdot 71$ & $5 \cdot 20$ & $5 \cdot 34$ \\
\hline Normal, with added glucose $(20 \mathrm{mg} / \mathrm{ml})$ & None & $6 \cdot 20$ & $6 \cdot 87$ & $5 \cdot 30$ & $5 \cdot 54$ \\
\hline
\end{tabular}

Bacterial counts $\left(\log _{10} / \mathrm{ml}\right)$ before incubation $=* 5.63$ and $\uparrow 5.08$.

Table V. Growth of E. cloacae 113 and $S$. marcescens K-3 in nutrient broth, with and without the addition of different concentration of urea

\begin{tabular}{|c|c|c|c|c|}
\hline \multirow{3}{*}{$\begin{array}{l}\text { Urea concen- } \\
\text { tration (mg/ } \\
\mathrm{ml})\end{array}$} & \multicolumn{4}{|c|}{$\begin{array}{l}\text { Bacterial counts }\left(\log _{10} / \mathrm{ml}\right) \text { after the stated } \\
\text { periods of incubation in broth seeded with }\end{array}$} \\
\hline & \multicolumn{2}{|c|}{ E. cloacae $113^{*}$} & \multicolumn{2}{|c|}{ S. marcescens $\mathrm{K}-3 \dagger$} \\
\hline & $2 \mathrm{~h}$ & $4 \mathrm{~h}$ & $2 \mathrm{~h}$ & $4 \mathrm{~h}$ \\
\hline 0 & $6 \cdot 30$ & $7 \cdot 80$ & $6 \cdot 24$ & $7 \cdot 82$ \\
\hline 10 & $6 \cdot 25$ & 7.73 & $6 \cdot 15$ & $7 \cdot 39$ \\
\hline 30 & 6.00 & $7 \cdot 37$ & $5 \cdot 80$ & 6.57 \\
\hline 50 & $5 \cdot 70$ & $6 \cdot 26$ & $5 \cdot 00$ & 4.85 \\
\hline
\end{tabular}

Bacterial counts $\left(\log _{10} / \mathrm{ml}\right)$ before incubation $=* 5 \cdot 26$ and $\uparrow 5 \cdot 41$.

have shown that normal mouse urine possessed bacteriostatic properties for $S$. marcescens and $E$. cloacae but that urine from diabetic mice supported bacterial growth. The addition of glucose $20 \mathrm{mg} / \mathrm{ml}$ to normal urine to simulate the glycosuria of diabetes did not affect bacterial growth appreciably. Moreover, normal urine and urine from diabetic mice differed little in $\mathrm{pH}$. It seemed possible that the difference between the antibacterial properties of the two types of urine might be related to urea

\section{REFERENCES}

Cox C E, Hinman F 1961 Experiments with induced bacteriuria, vesicle emptying and bacterial growth on the mechanism of bladder defense to infection. Journal of Urology 86: 739748.

Cruickshank A H 1954 Resistance to infection in the alloxan- nitrogen content. Kaye (1968) reported that the antibacterial activity of urine was related to urea concentration, and to a lesser degree to osmolality and ammonia concentration. Neter and Clark (1944) demonstrated that urea added to urine in concentrations ranging from 3.1 to $6.3 \mathrm{mg} / \mathrm{ml}$ greatly increased antibacterial activity, and Hadas et al. (1977) reported similar findings. Jackson and Grieble (1957) found, however, that the addition of urea to urine in a concentration of only $0.5 \mathrm{mg} / \mathrm{ml}$ did not inhibit multiplication of bacteria. In the present experiments the addition of urea to urine from diabetic mice rendered it partly bacteriostatic or bactericidal to $E$. cloacae and $S$. marcescens. The intensity of the effect increased with the concentration of urea. The decreased antimicrobial activity of urine in diabetic mice may result from the dilution of inhibitory substances such as urea by diuresis; it is well known, however, that the decrease of urea nitrogen content in human diabetic patients with ketoacidosis is due to the increase of ammonia concentration.

Possibly the susceptibility of diabetic mice to bladder infection is due to a combination of low antibacterial activity of the urine, a depression of the hosts' defences, and to a recently demonstrated (unpublished) increase in the adhesive capacity of bladder epithelial cells, but further studies are needed.

diabetic rabbit. Journal of Pathology and Bacteriology 67: 323-334.

Davis E G, Hain R F 1918 Urinary antisepsis. The antiseptic properties of normal dog urine. Journal of Urology 2: 309320.

Edwards M S, Fuselier P A 1983 Enhanced susceptibility of mice with streptozotocin-induced diabetes to type II group 
B streptococcal infection. Infection and Immunity 39: 580585.

Forland M, Thomas V, Shelokov A 1977 Urinary tract infections in patients with diabetes mellitus. Studies on antibody coating of bacteria. Journal of the American Medical Association 238: 1924-1926.

Hadas H, Medalia O, Aronson M 1977 Differential susceptibility of Escherichia coli and Proteus mirabilis to mouse urine and to urea. Journal of Infectious Diseases 136: 100-103.

Jackson G G, Grieble H G 1957 Pathogenesis of renal infection. Archives of Internal Medicine 100: 692-700.

Kaye D 1968 Antibacterial activity of human urine. Journal of Clinical Investigation 47: 2374-2390.

Neter E R, Clark P 1944 The combined antimicrobial activity of urea and sulfathiazole in urine. Journal of Urology 51 : 101-109.

Obana Y, Nishino T, Tanino T $1985 a$ In-vitro and in-vivo activities of antimicrobial agents against Acinetobacter calcoaceticus. Journal of Antimicrobial Chemotherapy 15: 441-448.

Obana Y, Nishino T, Tanino T $1985 b$ Therapeutic efficacy of $\beta$ lactam and aminoglycoside antibiotics on experimental pneumonia caused by Klebsiella pneumoniae B-54 in diabetic mice. Journal of Antibiotics 38: 941-947.

Obana Y, Nishino T, Tanino T 1987 Enhanced susceptibility of diabetic mice to gram-negative organisms. Nihon Saikingaku Zasshi (Japanese Journal of Bacteriology) 42: 653-661 (in Japanese).

Okuda J, Ohara A, Watanabe F (eds) 1981 RinshoukagakuJisshusho. The Hirokawa-Shoten, Tokyo, pp 93-95.

Raffel L, Pitsakis P, Levison S P, Levison ME 1981 Experimental Candida albicans, Staphylococcus aureus, and Streptococcus faecalis pyelonephritis in diabetic rats. Infection and Immunity 34: 773-779. 